\title{
DOENÇAS OCULARES EXTERNAS
}

\author{
EXTERNAL OCULAR DISEASES
}

Sidney Júlio de Faria e Sousa

Docente do Departamento de Oftalmologia e Otorrinolaringologia da Faculdade de Medicina de Ribeirão Preto da Universidade de São Paulo.

CoRRESPONDÊNCIA: Sidney Júlio de Faria e Sousa. Departamento de Oftalmologia e Otorrinolaringologia da Faculdade de Medicina de Ribeirão Preto da Universidade de São Paulo - Campus Universitário - CEP: 14048-900 - Ribeirão Preto - SP. FAX: (016) 633-0186.

FARIA E SOUSA SJ de. Doenças oculares externas. Medicina, Ribeirão Preto, 30: 52-55, jan./mar. 1997.

RESUMO: O olho vermelho é um sinal que esconde um grande número de enfermidades oculares. Diante desse sinal, é preciso diferenciar os casos simples dos perigosos. Para tanto, devem-se conhecer os sinais e sintomas oculares sugestivos de gravidade. As úlceras, o glaucoma e as uveítes anteriores são as três grandes ameaças à visão associadas ao olho vermelho. A conjuntivite do recém-nascido também deve ser considerada grave pela potencialidade da origem gonocócica ou por clamydias. As conjuntivites agudas, blefarites, hordéolos e calázios, em geral, não são graves. Por motivos econômicos, o diagnóstico laboratorial destas últimas só se justifica quando elas forem refratárias ao tratamento usual.

UNITERMOS: Hiperemia. Inflamação. Oftalmopatias. Olho.

A queixa de olho vermelho deve-se, freqüentemente, a uma anormalidade simples como uma conjuntivite de pequena gravidade, uma hemorragia subconjuntival, um hordéolo ou uma blefarite. Essas condições, em geral, ou melhoram espontaneamente, ou são facilmente tratadas pelo clínico geral. Ocasionalmente, o problema é mais grave, merecendo envio direto ao oftalmologista. Nesses casos, é fundamental que o clínico identifique a seriedade da situação para que o encaminhamento não seja retardado.

As três grandes ameaças à visão são: as ceratites, iridociclites e glaucomas agudos. As ceratites são inflamações da córnea. Na maioria das vezes, decorrem de infecções bacterianas ou fúngicas pós-traumas. Iridociclites são inflamações da íris e corpo ciliar que se manifestam por exsudação protéica, dentro da câmara anterior. Na maior parte das vezes, surgem de traumas contusos como um soco, por exemplo. Glaucoma agudo é um aumento súbito da pressão intra-ocular que ocorre em olhos predispostos, geralmente, na velhice.

As três condições são acompanhadas de dor ocular, embora com padrões diferentes. A dor da ceratite é aguda e acompanhada de lacrimejamento e blefaroespasmo. A grande pista diagnóstica é o fato de sumir com a instilação de anestésicos, o que não acontece com as demais patologias. A dor da iridociclite é maior à palpação. A dor se origina do espasmo do músculo ciliar e, por isso, melhora com o uso da atropina e derivados sintéticos. A dor do glaucoma 
agudo tende a ser intensa e acompanhada de vômitos. O paciente típico é um idoso. A dor não piora com a palpação, mas a manobra é importante, porque revela um grande endurecimento do globo ocular. A pupila também não reage à luz, em virtude da pressão elevada. A instilação de midriáticos piora o quadro.

Além dessas enfermidades, um grande número de outras também causam vermelhidão do olho. A maioria, porém, tende a ter pouca gravidade. Exemplos típicos, são as conjuntivites, episclerites, hemorragias subconjuntivais e blefarites.

As conjuntivites são inflamações difusas da conjuntiva com variada gama etiológica. As causas mais freqüentes são as infecções bacterianas, viróticas e alérgicas. O tipo de secreção dá uma pista da causa da enfermidade. Secreção mucopurulenta sugere etiologia bacteriana. Secreção serosa (aquosa) aponta para viral. Muco hialino e filamentoso indica origem alérgica, principalmente, quando acompanhado de coceira. A principal queixa da conjuntivite é a sensação de corpo estranho e turvação visual. Normalmente não há dor. A turvação melhora com o piscar, porque decorre do acúmulo de secreção. Episclerites são vermelhidões localizadas do olho. Diferenciam-se das conjuntivites justamente pelo fato de serem localizadas e sem secreção. Por vezes, são acompanhadas de dor que melhora espontaneamente. Não têm maiores conseqüências para o olho. As hemorragias conjuntivais são coleções de sangue debaixo da conjuntiva. Na maioria das vezes, resultam do sangramento de pequenos vasos conjuntivais, após esforços como, por exemplo, o de evacuar. São típicos de pessoas idosas com prisão de ventre. Desaparecem lenta e progressivamente, sem tratamento. As blefarites são inflamações crônicas das bordas palpebrais, resultantes da superpopulação de estafilococos. O olho fica constantemente avermelhado por irritação das toxinas bacterianas. $\mathrm{O}$ diagnóstico é freqüentemente perdido, se não se estiver alerta para o fato.

\section{COMO EXAMINAR O OLHO COM HIPEREMIA OCULAR}

Em primeiro lugar, deve-se medir a acuidade visual. Em seguida, decidir, através da inspeção se a vermelhidão se deve: ao ingurgitamento dos vasos conjuntivais (hiperemia conjuntival), à turgescência dos vasos profundos episclerais que circundam a córnea (injeção ciliar), à hemorragia subconjuntival ou qualquer combinação destas. Das três primeiras possibilidades, a injeção ciliar é a que mais probabilidade tem de estar associada a uma enfermidade grave. Ela acompanha as ceratites, uveítes anteriores e glaucoma.

O próximo passo é detectar rupturas do epitélio corneano. Com o auxílio de uma lanterna, tenta-se identificar distorções do reflexo luminoso na córnea. Elas, freqüientemente, associam-se às soluções de continuidade do epitélio. Em seguida, aplica-se a fluoresceina e procura-se por áreas coradas de verde.

A profundidade da câmara anterior e a identificação de sangue ou pus no seu interior, também podem ser feitas com lanterna. Incidindo a luz lateralmente, se a câmara é profunda, toda a íris é iluminada. Se é rasa, a íris do lado oposto aparece mais escura. Acúmulos de sangue (hifema) ou pus (hipópio), desenham uma meia lua no pólo inferior da câmara anterior. As irregularidades de tamanho e forma da pupila são melhor apreciadas, comparando-se ambos os olhos.

A avaliação da pressão ocular deve ser feita sempre que houver hiperemia ocular sem causa aparente. Com os dois dedos indicadores encostados, pressiona-se o pólo superior do olho, por cima da pálpebra superior, procurando sentir a tensão do mesmo. Facilita-se o exame, pedindo ao paciente que olhe para baixo.

Quando houver um aumento da secreção conjuntival, procure caracterizá-la em: purulenta - branco cremosa; mucopurulenta - amarelada; serosa - aquosa amarelada; mucosa - filamentar e transparente.

\section{SINAIS E SINTOMAS DO OLHO VERMELHO}

É importante que o examinador conheça os sinais sugestivos de gravidade, diferenciando-os dos menos importantes. Os principais sinais sugestivos de gravidade são:

1 - Congestão ciliar: caracteriza-se pelo turgescência dos vasos do corpo ciliar. São vasos profundos, de cor vermelho-azulado, que partem do limbo com padrão radiado. $\mathrm{O}$ fenômeno é característico das iridociclites, mas também acompanha o glaucoma agudo e as ceratites. Decorre da inflamação do corpo ciliar. 
2 - Soluções de continuidade do epitélio corneano: a perda focal do epitélio corneano tem alto risco, pois facilita a infecção da córnea. A perda epitelial pura não caracteriza uma úlcera. O nome "úlcera" é reservado para os casos em que exista um comprometimento adicional do estroma subjacente. Ceratite, é um termo genérico para qualquer inflamação da córnea, acompanhada, ou não, de perda do epitélio.

3 - Câmara anterior rasa: na presença de hiperemia ocular, e não havendo história de perfuração, deve-se suspeitar de glaucoma agudo; particularmente, se o paciente for idoso.

4 - Anormalidade do tamanho e forma da íris: na iridociclite, a pupila é usualmente menor, devido ao espasmo do esfíncter da íris. No glaucoma agudo, ela se apresenta semidilatada e imóvel. Pupila em "gota d'água" é sinal de perfuração ocular.

5 - Pressão ocular alterada: das condições que causam olho vermelho, somente o glaucoma e a iridociclite interferem com a pressão ocular.

\section{Os sintomas sugestivos de gravidade incluem:}

1 - Visão borrada, que não desaparece com o piscar, é sinal de gravidade. Não ocorre nas conjuntivites, a menos que haja envolvimento corneano ou do corpo ciliar.

2 - Dor é outro sintoma sugestivo de problema sério. Também não ocorre nas conjuntivites. A episclerite é uma das poucas exceções à regra. Embora sem gravidade, às vezes dá dor aguda.

3 - Fotofobia, é uma aversão à luz, própria das iridociclites e ceratites. Não ocorre nas conjuntivites comuns.

4 - Halos coloridos são arco-íris em torno da luz. Acompanham o edema de córnea secundário, ao aumento da pressão ocular.

São sinais de menor gravidade: hiperemia conjuntival, secreção e aumento dos gânglios pré-auriculares. O primeiro, é um sinal inespecífico, que pode ser encontrado em qualquer condição causadora de olho vermelho. O último, é freqüente nas conjuntivites viróticas. Outros sintomas freqüentes são, o lacrimejamento e o prurido. Nenhum dos dois expressa gravidade. O primeiro é típico da conjuntivite, freqüente nas ceratites e ocasional nas blefarites. Não ocorre na iridociclite e glaucoma. O segundo é característico das conjuntivites alérgicas. Muitas vezes, o prurido é o único elemento diagnóstico da alergia.

\section{DIAGNÓSTICO LABORATORIAL}

O exame da exsudato conjuntival pode confirmar impressões clínicas. Nas conjuntivites bacterianas, eles revelam bactérias e abundância de polimorfonucleados. Nas conjuntivites virais, predominam os linfócitos. Nas infecções por clamydias, prevalece a mistura de ambas as células. Nas alergias, dominam os eosinófilos.

As culturas e antibiogramas são úteis para a determinação do agente patogênico e a sensibilidade aos antibióticos. Entretanto, todos esses exames são subsidiários. Isto significa que, se o médico não tiver impressões diagnósticas em mente, é muito provável que eles mais atrapalhem do que ajudem. Um exame de cultura, num olho com deficiência de lágrimas, pode muito bem revelar estafilococos, sem que estes sejam a causa da irritação do olho.

\section{TRATAMENTO}

A maioria das conjuntivites é tratada sem auxílio laboratorial, por razões econômicas. As conjuntivites bacterianas são tratadas com colírio antibiótico de amplo espectro. As instilações devem ser, no mínimo, a cada três horas. Os casos que não respondem em dois dias de tratamento, devem ser encaminhados ao oftalmologista. As conjuntivites virais não têm tratamento específico.

As hemorragias subconjuntivais não necessitam de tratamento. Nas blefarites, procura-se erradicar a infecção estafilocócica crônica com aplicações diárias de ungüento antibacteriano, nas bordas palpebrais. Essas aplicações são precedidas de rigorosa limpeza local. A sintomatologia dos hordéolos é aliviada com calor local, até que a condição drene espontânea ou cirurgicamente. A antibioticoterapia tópica é de valor questionável. As ceratites, iridociclites e glaucomas agudos devem ser encaminhados, com presteza, ao oftalmologista. 
FARIA E SOUSA SJ de. External ocular diseases. Medicina, Ribeirão Preto, 30: 52-55, jan./march 1997.

ABSTRACT: Red eye is a sign that hides a great number of ocular diseases. Finding this sign, it is a must to differentiate the simple from risky cases. To do so, one should know the signs and symptoms indicative of seriousness. Ulcers, glaucoma and anterior uveitis are the three big threats to the eyesight associated with red eye. The newborn conjunctivitis is also considered a serious disease because the potentiality of gonococcal or chlamydial origin. Acute conjunctivitis, ordeola and chalazia are not risky in general. For economic reasons the laboratorial workup of the later is justifiable only when they were refractory to the current medications.

UNITERMS: Hyperemia. Inflammation. Eye Diseases. Eye.

\section{BIBLIOGRAFIA CONSULTADA}

1 - ARFFA RC. Diseases of the cornea. 3 ed. Mosby, St. Louis, 1991.
2 - DUANE TD. Clinical ophthalmology, Harper \& Row Publishers, Hagerstown, 1996.

Recebido para publicação em 03/01/97

Aprovado para publicação em 30/01/97 